\title{
Effect of Treated Wastewater Irrigation on Heavy Metals Distribution in a Tunisian Soil
}

\author{
Khawla Khaskhoussy \\ Institute of Rural Engineering, Waters \\ and Forest and INAT \\ Ariana, Tunisia \\ khawla.khaskhoussy@yahoo.fr
}

\author{
Omar Jozdan \\ ACSAD \\ Damascus, Syria \\ omar62@hotmail.com
}

\author{
Besma Kahlaoui \\ INRGREF \\ Ariana, Tunisia \\ besma.kahlaoui@gmail.com
}

\author{
Abdullah Dakheel \\ ICBA, Oman \\ a.dakheel@biosaline.org.ae
}

\author{
Besma Messoudi Nefzi \\ INRGREF \\ Ariana, Tunisia \\ messoudi.b@gmail.com
}

\author{
Mohamed Hachicha \\ INRGREF \\ Ariana, Tunisia \\ hachicha.mohamed@iresa.agrinet.tn
}

\begin{abstract}
Treated wastewater (TWW) may contain toxic chemical constituents that pose negative environmental and health impacts. In this study, soil samples under treated wastewater irrigation were studied. For this purpose, six plots were made in an irrigated area in north of Tunisia and treated with two water qualities: fresh water (FW) and treated wastewater (TWW). Five soil depths were used: 0-30, 30-60, 6090, 90-120 and 120-150 cm. The TWW irrigation increased significantly (P $\leq 0.05)$ the soils' $\mathrm{EC}, \mathrm{Na}, \mathrm{K}, \mathrm{Ca}, \mathrm{Mg}, \mathrm{Cl}, \mathrm{SAR}, \mathrm{Cu}$, $\mathrm{Cd}$ and $\mathrm{Ni}$ and had no significant $(\mathrm{P} \leq \mathbf{0 . 0 5})$ effect on the soils' $\mathrm{pH}$, $\mathrm{Zn}, \mathrm{Co}$ and $\mathrm{Pb}$ contents. EC, Na, Cl, SAR, Zn and Co increased significantly with soil depth. The results for $\mathrm{K}, \mathrm{Ca}, \mathrm{Mg}, \mathrm{Cd}, \mathrm{Pb}$ and Ni exhibited similar repartition in different layers of soil. It was also shown that the amount of different elements in soil irrigated with fresh water (FW) were less compared with the control soil.
\end{abstract}

Keywords- TWW; FW; soil; salinity; Heavy metals; Tunisia

\section{INTRODUCTION}

In many arid and semi-arid regions, natural fresh water (FW) resources are limited, whereas the demand is constantly increasing due to industrial and population growth. The greater challenge to meet water demands and manage its limited natural resources has led to the use of alternative irrigation sources [1]. One of these alternatives is to use nonconventional water resources, such as Treated Waste Water (TWW). The reuse of TWW for purposes such as agricultural irrigation has become, for many countries, an important element in water resources planning [2]. TWW can be used to help in reducing natural water consumption, in restoring and preserving degraded land and in aiding the growth of vegetation [3-7].

The reuse of TWW for irrigation is considered an environmentally sound wastewater disposal practice compared to its direct disposal to the surface or ground water bodies. In addition, TWW provides convenient disposal of waste products [8] and constitutes a significant source of plant nutrients and organic matter needed for maintaining the fertility and productivity levels of the soil $[9,10]$. However, besides these beneficial effects, TWW is often associated with environmental and health risks. The main health risks are associated with the contamination of crops or ground waters by TWW due to its chemical composition being somewhat different from most natural waters used in irrigation [11]. This water may contain high levels of salts, toxic ions, heavy metals, and organic residues. Accumulation of these pollutants in soil can be harmful in fields irrigated for longs periods of time and poses a threat to agricultural production and the environment [12].

Several studies have reported some changes in the physicochemical characteristics of soil due to TWW application [13, 14] such as the increase of soil salinity, electrical conductivity (EC), organic matter, exchangeable $\mathrm{Na}$, $\mathrm{K}, \mathrm{Ca}, \mathrm{Mg}$, plant available phosphorus and microelements [1417] and the decrease of soil $\mathrm{pH}$ [16]. In general, heavy metals combine with other anions or anionic compounds to form stable substances and tend to accumulate in the topsoil (0-35 $\mathrm{cm})$. Furthermore, their uptake by plants increases with decreasing $\mathrm{pH}$, due to the dissolution of metal-carbonate complexes that releases free metal ions into the solution [18]. However, when the capacity of soils to retain toxic metals is reduced due to continuous loading of pollutants or changes in $\mathrm{pH}$, metal ions that have a relatively high mobility can migrate in depth and contaminate groundwater by percolation into the ground [19].

The purpose of the present work is to study and compare the effects of FW and TWW irrigation on a Tunisian clay loam soil properties and its macro- and micro-nutrients, and heavy metal content, in order to establish the basis for safe TWW agricultural reuse. 


\section{MATERIALS AND METHODS}

\section{A. Experimental design}

The experiment was located in Cebela Borj-Touil field located $20 \mathrm{~km}$ north of Tunisian the Low Valley of Medjerda. Climate of the region is semi-arid with an annual rainfall close to $470 \mathrm{~mm}$ and an average yearly evapotranspiration of 1400 $\mathrm{mm}$. The soil is clay-loam. The experiment included two sources of irrigation water: (a) TWW and FW (b). The experiment was carried out in strip plot design with three replications and a total of $2 \times 3=6$ plots of $3 \mathrm{mx} 3=9 \mathrm{~m}^{2}$ size. The experimental plots were irrigated by wastewater from Chotrana treatment plant located in north of Tunis city.

The TWW and FW were applied during the summer period. In each plot, soil samples were collected from five successive depths 0-30, 30-60, 60-90, 90-120 and 120-150 cm. Control soil samples were collected in the beginning of the experiment. Water samples were collected periodically during the experimental period and the chemical characteristics are summarized in Table I.

TABLE I. CHEMICAL PROPERTIES OF FW AND TWW

\begin{tabular}{|c|c|c|c|}
\hline \multirow{2}{*}{ Parameter } & \multicolumn{2}{|c|}{ Irrigated water } & INNORPI (NT-1989)* \\
\hline & FW & & \\
\hline $\mathrm{pH}$ & $8.5 \mathrm{~b}$ & $6.5-8.5$ & $6.5-8.5$ \\
\hline $\mathrm{EC}\left(\mathrm{dSm}^{-1}\right)$ & $1.42 \mathrm{a}$ & 7 & 7 \\
\hline $\mathrm{SO}^{-}\left(\mathrm{mgl}^{-1}\right)$ & $9.47 \mathrm{a}$ & - & - \\
\hline $\mathrm{Na}^{+}\left(\mathrm{mgl}^{-1}\right)$ & $6.45 \mathrm{a}$ & & - \\
\hline $\mathrm{Ca}^{++}\left(\mathrm{mgl}^{-1}\right)$ & $6.28 \mathrm{a}$ & - & - \\
\hline $\mathrm{Mg}^{++}\left(\mathrm{mgl}^{-1}\right)$ & $4.91 \mathrm{a}$ & - & 2000 \\
\hline $\mathrm{Cl}^{-}\left(\mathrm{mgl}^{-1}\right.$ & $9.39 \mathrm{a}$ & 2000 & \\
\hline $\mathrm{K}^{+}\left(\mathrm{mgl}^{-1}\right.$ & $0.14 \mathrm{a}$ & & 0.05 \\
\hline $\left.\mathrm{Cd}^{-1} \mathrm{mgl}^{-1}\right)$ & $0.045 \mathrm{a}$ & 0.05 & 0.1 \\
\hline $\mathrm{Co}\left(\mathrm{mgl}^{-1}\right)$ & $0.033 \mathrm{a}$ & 0.1 & 0.2 \\
\hline $\mathrm{Cu}\left(\mathrm{mgl}^{-1}\right)$ & $0.019 \mathrm{a}$ & 0.2 & 0.2 \\
\hline $\mathrm{Ni}\left(\mathrm{mgl}^{-1}\right)$ & $0.06 \mathrm{a}$ & 0.2 & 5 \\
\hline $\mathrm{Pb}\left(\mathrm{mgl}^{-1}\right)$ & $0.16 \mathrm{a}$ & 5 & 2 \\
\hline $\mathrm{Zn}\left(\mathrm{mgl}^{-1}\right)$ & $0.010 \mathrm{a}$ & 2 & $*$ Tunisian Standard \\
\hline
\end{tabular}

\section{B. Soil sampling and analysis}

Collected soil samples were transported to the laboratory, oven, dried at $105^{\circ} \mathrm{C}$ and sieved for chemical analysis. The $\mathrm{pH}$ and the electric conductivity (EC) were respectively measured with pH-meter and conductivity-meter in a soil-water suspension.

The sodium absorption ratio (SAR) [20] was calculated by the following formulae:

$$
\mathrm{SAR}=\frac{[\mathrm{Na}]}{\sqrt{\left[\mathrm{Ca}^{2+}\right]+\left[\mathrm{Mg}^{2+}\right]}}
$$

Concentrations of $\mathrm{Ca}$ and $\mathrm{Mg}$ were measured using the EDTA titration method. $\mathrm{Na}$ and $\mathrm{K}$ contents were measured using flame photometer [20]. Soil samples were digested for heavy metal $(\mathrm{Cu}, \mathrm{Zn} \mathrm{Cr}, \mathrm{Cd}, \mathrm{Ni}$ and $\mathrm{Pb})$. The procedure based on acid digestion induced by microwave energy was optimized in order to measure the total heavy metals contents in soils. Each soil sample $(1 \mathrm{~g})$ was placed in a Teflon vessel $(100 \mathrm{~mL})$ with $\mathrm{HF}(10 \mathrm{~mL})$ and $\mathrm{HClO}_{4}(5 \mathrm{~mL})$ and then digested in a microwave. After that, $70 \mathrm{ml}$ of perchloric acid was added to the mixture. After digestion, the samples were filtered and transferred into $100 \mathrm{ml}$ volumetric flasks and brought to volume of $100 \mathrm{ml}$ by added of distilled water. The filtrate was analyzed by atomic absorption for the determination of the following: $\mathrm{Mn}, \mathrm{Cu}, \mathrm{Fe}, \mathrm{Pb}$, $\mathrm{Co}$ and $\mathrm{Ni}$ (ISO 14869-1, 2001).

\section{Statistical analysis}

The statistical analyses were performed for each parameter in each soil layer and for different treatment. The data were subjected to one-way analysis of variance (ANOVA) using STATISTICA software, Version 5 (Statsoft France, 1997). Mean comparison was carried out using LSD test at the significant level of 0.05 .

\section{RESULTS}

\section{A. Soil $p H$}

As showed in Table II, $\mathrm{pH}$ of soil has not been significant altered in the treated soils. The $\mathrm{pH}$ is low in the depth of soil of $90-120 \mathrm{~cm}$. A low value of $\mathrm{pH}$ was noted in all treated soils.

\section{B. Soil Electrical Conductivity (EC)}

According to Table II, the soil EC was significantly increased in two depths (30-60 and 60-90 cm). This increase was, respectively, from 2.72 to 4.49 and 7.9 to $8.21 \mathrm{dSm}^{-1} 1$. The data obtained after FW application indicated that EC was decreased, respectively, from 6.13 to 4.38 and from 7.91 to $5.78 \mathrm{dSm}^{-1}$ in $90-120$ and $120-150 \mathrm{~cm}$ soil depth.

TABLE II. EFFECTS OF TWW ON PH AND EC OF SOIL

\begin{tabular}{|l|l|c|c|c|c|c|}
\hline \multirow{3}{*}{ Parameter } & \multicolumn{7}{|c|}{ Soil layers (cm) } \\
\cline { 2 - 7 } & Treatment & $\mathbf{0 - 3 0}$ & $\mathbf{3 0 - 6 0}$ & $\mathbf{6 0 - 9 0}$ & $\mathbf{9 0 - 1 2 0}$ & $\begin{array}{c}\mathbf{1 2 0}- \\
\mathbf{1 5 0}\end{array}$ \\
\hline \multirow{3}{*}{$\mathrm{pH}$} & Control & $8 \mathrm{bcd}$ & $8 \mathrm{bcd}$ & $8,21 \mathrm{~cd}$ & $7,71 \mathrm{ab}$ & $8.17 \mathrm{c}$ \\
\cline { 2 - 8 } & FW & $8 \mathrm{bcd}$ & $8 \mathrm{bcd}$ & $8,2 \mathrm{~cd}$ & $7,7 \mathrm{ab}$ & $8.2 \mathrm{~cd}$ \\
\cline { 2 - 7 } & TWW & $7.9 \mathrm{bcd}$ & $8 \mathrm{bcd}$ & $8.17 \mathrm{~cd}$ & $7.58 \mathrm{ab}$ & $8.2 \mathrm{~cd}$ \\
\hline \multirow{3}{*}{$\mathrm{EC}$} & Control & $2,73 \mathrm{a}$ & $2,72 \mathrm{a}$ & $3,53 \mathrm{ab}$ & $6,13 \mathrm{c}$ & $7,91 \mathrm{~d}$ \\
\cline { 2 - 8 } & FW & $2,73 \mathrm{a}$ & $2,72 \mathrm{a}$ & $3,51 \mathrm{ab}$ & $4,38 \mathrm{~b}$ & $5,78 \mathrm{c}$ \\
\cline { 2 - 7 } & TWW & $3,25 \mathrm{a}$ & $4,49 \mathrm{~b}$ & $5,94 \mathrm{c}$ & $6,13 \mathrm{c}$ & $7,97 \mathrm{~d}$ \\
\hline
\end{tabular}

\section{Major elements contents}

The results for $\mathrm{Na}, \mathrm{K}, \mathrm{Ca}, \mathrm{Mg}$ and $\mathrm{Cl}$ are summarized in Table III. The TWW treatment led to an increase in Na content in the soil particularly at the depth of the $0-30 \mathrm{~cm}$. In comparison to the control treatment, the $\mathrm{Na}$ content was increased from 19.5 to 32.75 meq. $\mathrm{L}^{-1}$. For K content, the TWW treatment applied increased significantly the $\mathrm{K}$ content in a soil depth of 0-30 cm compared to the control and FW treatment of soil. The $\mathrm{K}$ amount in th control soil was 0,34 meq. $\mathrm{L}^{-1}$ and was increased significantly to 4.47 meq. $\mathrm{L}^{-1}$ with the irrigation with TWW. The Ca content in soil irrigated with TWW was significantly higher in the soil depth of $0-30 \mathrm{~cm}$ compared to the control treatment. The application of TWW led to an 
increase of $\mathrm{Mg}$ content especially in the soil depths of 0-30 and 90-120 cm. As showed in the Table III, the $\mathrm{Cl}$ content was greater in soil depths of $0-30$ and $90-120 \mathrm{~cm}$ with the TWW application.

\section{Soil sodicity (SAR)}

As shown in Table III, the SAR values were not significantly affected by the different waters qualities. However, in all treatments, the SAR level increased significantly with the increasing of soil depth. .

TABLE III. OIL CHEMICAL CHARACTERISTICS

\begin{tabular}{|c|c|c|c|c|c|c|}
\hline \multirow{2}{*}{$\begin{array}{c}\text { Paramet } \\
\text { er }\end{array}$} & \multicolumn{6}{|c|}{ Soil layers (cm) } \\
\hline & Treatment & $0-30$ & $30-60$ & $60-90$ & $90-120$ & $120-150$ \\
\hline \multirow{3}{*}{$\mathrm{Na}$} & Control & $19,5^{\text {a }}$ & $27^{\mathrm{ab}}$ & $45,79^{\text {de }}$ & $54,05^{\text {efg }}$ & $61,15^{\mathrm{g}}$ \\
\hline & FW & $17,17^{\mathrm{a}}$ & $19,4^{\mathrm{a}}$ & $41,3 \mathrm{~cd}$ & $53,3^{\text {defg }}$ & $51^{\operatorname{defg}}$ \\
\hline & TWW & $32,7^{\mathrm{bc}}$ & $29^{a b}$ & $48,2^{\text {def }}$ & $54,56^{\text {fg }}$ & $61,44^{\mathrm{g}}$ \\
\hline \multirow{3}{*}{ K } & Control & $0,34^{\mathrm{a}}$ & $0,09^{\mathrm{a}}$ & $0,17^{\mathrm{a}}$ & $0,11^{\mathrm{a}}$ & $0,17^{\mathrm{a}}$ \\
\hline & FW & $0,11^{\mathrm{a}}$ & $0,07^{\mathrm{a}}$ & $0,1^{\mathrm{a}}$ & $0,11^{\mathrm{a}}$ & $0,13^{\mathrm{a}}$ \\
\hline & TWW & $4,47^{\mathrm{b}}$ & $0,79^{\mathrm{a}}$ & $1,75^{\mathrm{a}}$ & $1,28^{\mathrm{a}}$ & $1,16^{\mathrm{a}}$ \\
\hline \multirow{3}{*}{$\mathrm{Ca}$} & Control & $6,7 \mathrm{a}^{\mathrm{bc}}$ & $6,1 \mathrm{a}^{\mathrm{b}}$ & $8,7^{\text {abcd }}$ & $14^{\mathrm{e}}$ & $11,4^{\text {cde }}$ \\
\hline & FW & $5,44^{\mathrm{a}}$ & $5,03 \mathrm{a}$ & $8,1^{\text {abcd }}$ & $8,23^{\text {abcd }}$ & $8,56^{\mathrm{abcd}}$ \\
\hline & TWW & $11^{\text {bcde }}$ & $6,7^{\mathrm{abc}}$ & $10^{\text {abcde }}$ & $14,14^{\mathrm{e}}$ & $12,93^{\mathrm{de}}$ \\
\hline \multirow{3}{*}{$\mathrm{Mg}$} & Control & $3,22^{\mathrm{a}}$ & $5^{a b c}$ & $6,64^{\text {cde }}$ & $8,38^{\text {cde }}$ & $8,8^{\mathrm{de}}$ \\
\hline & FW & $5^{a b c}$ & $3,7^{\mathrm{ab}}$ & $6,5^{\text {abcd }}$ & $8,26^{\text {cde }}$ & $7,6^{\text {cde }}$ \\
\hline & TWW & $7,6^{\text {cde }}$ & $5,2^{\mathrm{abc}}$ & $6,73^{\text {bed }}$ & $10,29^{\mathrm{e}}$ & $9,29^{\mathrm{de}}$ \\
\hline \multirow{3}{*}{$\mathrm{Cl}$} & Control & $15,68^{\mathrm{a}}$ & $22^{\mathrm{ab}}$ & $30,22^{b c}$ & $54,75^{\text {ef }}$ & $54,14^{\text {ef }}$ \\
\hline & FW & $14,77^{\mathrm{a}}$ & $14,9^{\mathrm{a}}$ & $34,6^{\mathrm{abc}}$ & $45,47^{\text {def }}$ & $45,24^{\text {def }}$ \\
\hline & TWW & $30,3^{\text {bc }}$ & $24^{\mathrm{ab}}$ & $41,7^{\text {cde }}$ & $74,77^{f}$ & $58,01^{\mathrm{f}}$ \\
\hline \multirow{3}{*}{ SAR } & Control & $8,3^{\text {a }}$ & $10,8^{\mathrm{a}}$ & $17,35^{b}$ & $17,41^{b}$ & $18,85^{b}$ \\
\hline & FW & $7,87^{\mathrm{a}}$ & $9,33^{a}$ & $15,58^{b}$ & $16,40^{b}$ & $18,01^{b}$ \\
\hline & TWW & $10,77^{\mathrm{a}}$ & $11,9^{\mathrm{a}}$ & $16,45^{b}$ & $18,57^{\mathrm{b}}$ & $19,0^{\mathrm{b}}$ \\
\hline
\end{tabular}

\section{E. Heavy metal concentrations in soils}

\section{1) Zinc (Zn)}

According to Figure 1a, the $\mathrm{Zn}$ content in the soil samples irrigated with TWW was higher in the soil depth of 90-120 cm and didn't show a significant change in others soil depths compared to the control soil.

2) Cobalt (Co)

As shown in Figure $1 \mathrm{~b}$, the TWW treatment had a significant effect on Co content with the soil depth in comparison to the control treatment. The maximum Co content was $30.63 \mathrm{mg} \cdot \mathrm{kg}^{-1}$ and was found in the soil depth of $90-120$ $\mathrm{cm}$.

\section{3) Cupper $(\mathrm{Cu})$}

The TWW application increased significantly the $\mathrm{Cu}$ content with the soil depth in comparison with the control treatment. The highest increase was detected in the soil depth of $30-60$ and $90-120 \mathrm{~cm}$. This increase was from 8.56 and 8.1 $\mathrm{mg} . \mathrm{Kg}^{-1}$ to 16 and $16.66 \mathrm{mg} \cdot \mathrm{kg}^{-1}$ respectively (Figure $1 \mathrm{c}$ ).

\section{4) Cadmium (Cd)}

The results in Figure 1d showed a high accumulation of $\mathrm{Cd}$ contents in the case of TWW treatment in all soil depths compared to $\mathrm{Cd}$ content in the control soil and soil treated with the FW.

\section{5) Plomb $(\mathrm{Pb})$}

Results shown in Figure 1e indicate that TWW application increased significantly the $\mathrm{Pb}$ concentration $\left(126 \mathrm{mg} \cdot \mathrm{kg}^{-1}\right)$ in the soil depth of 0-30 of TWW irrigated soil as compared to control soil. While $\mathrm{Pb}$ concentration decreased due to irrigation with FW in all soil layers.

\section{6) Nickel (Ni)}

As presented in Figure 1f, TWW application to the soil led to significant increase of $\mathrm{Ni}$ content in all soil depths compared to the control soil and the soil treated with FW. Indeed, the highest levels of $\mathrm{Ni}$, with an average of $105.33 \mathrm{mg} \mathrm{kg}^{-1}$, were foundthe first soil depth $(0-30 \mathrm{~cm})$.
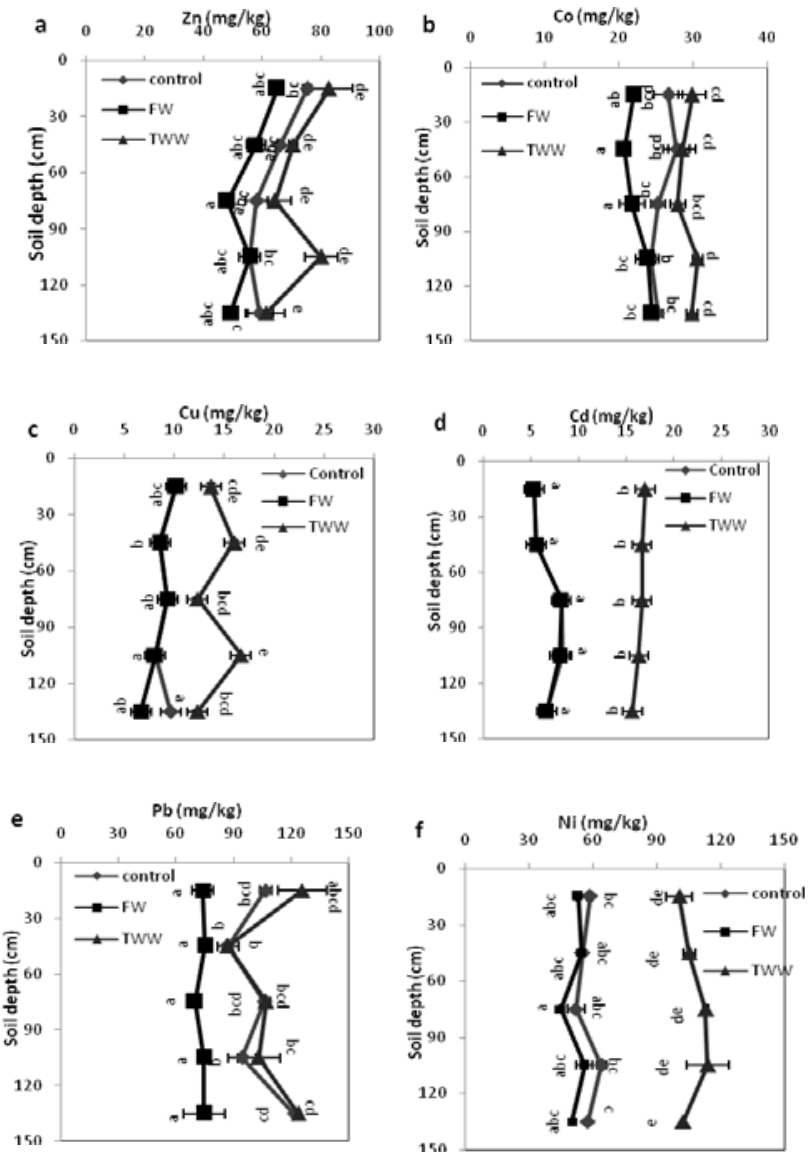

Fig. 1. Concentration of heavy metals $(\mathrm{mg} / \mathrm{kg})$ in the soil layers at the beginning of experiment and after irrigation with TWW and FW.

\section{DISCUSSION}

Soil $\mathrm{pH}$ is well known for his important role in the mobility of metals as in their bioavailability for plants [21, 22]. Indeed, metal availability is relatively low when $\mathrm{pH}$ is around 6.5 to 7 , as for lower $\mathrm{pH}$ would favor availability, mobility and redistribution of the metals. In the present study, result showed that the $\mathrm{pH}$ is around 7.5 and 8.2 and this statement limited the mobility of metal. Although irrigation with TWW led to a slight decrease of soil $\mathrm{pH}$ with depth, the soil was alkaline. Some investigations showed that irrigation with wastewater 
decreased the soil's $\mathrm{pH}$. This decrease was due to the decomposition of organic matter and production of organic acids. Others authors [23, 24 25] found that irrigation with TWW raised the soil $\mathrm{pH}$, respectively, by 1.3 and $0.2 \mathrm{U}$ of $\mathrm{pH}$. Other researchers $[10,11]$ explained this increase by the long term impact of irrigation with sewage and wastewater effluents on soil properties.

Results indicated that the electrical conductivity of soil irrigated with TWW increased significantly compared. Similar results were reported in [10, 12-13]. This increase has been attributed to the higher concentration of cations such as $\mathrm{Na}$ and $\mathrm{K}$ in wastewater [10]. This increase concerned soil depths of $30-60$ and $60-90 \mathrm{~cm}$. However, FW irrigation led to significant decrease of EC. In a similar way, Al-Nakshabandi et al. [14] explained this decrease by the leaching and displacement of salt after irrigation.

The results for Na showed high concentrations in the upper soil layer of TWW irrigated soil. This is in line [6]. However, a significant decrease of $\mathrm{Na}$ level was recorded in the first layer of FW irrigated soil. This decrease is probably due to the leaching of soluble $\mathrm{Na}$ into deeper soil layers [15].

The $\mathrm{K}$ concentration in TWW irrigated soil increased significantly compared to the control and FW irrigated soils. These results were in accordance with [13] but not in agreement with [16] that reported a decrease of K soil levels with TWW irrigation and explained this by root uptake and the leaching of $\mathrm{K}+$ into deeper soil. The concentrations of $\mathrm{Ca}$ in the first soil layer (0-30) of TWW irrigated soil samples were significantly higher than those in FW irrigated soil. Similarly, Heidarpour et al. [6] reported that irrigation with wastewater generated a greater $\mathrm{Ca}$ concentration than groundwater. They explained this statement by the difference in plant yield using two different irrigation waters and consequently the effect of plant uptake on the soil solution. FW led to a significant decrease on the average of $\mathrm{Ca}$ in most of soil layers. This reduction in soil $\mathrm{Ca}$ could be due to leaching, plant uptake and reaction of $\mathrm{Ca}$ with carbonate and sulfate, which were present in the water [6]. As for Mg, TWW increased significantly the $\mathrm{Mg}$ concentration in the first layer of soils compared to control soil in agreement with [6]. However, a significant decrease (of $\mathrm{Mg}$ level occurred in the case of the FW irrigation. This reduction has been reported as a possible in [1].

For $\mathrm{Cl}$ content, TWW caused significant increase of this element in soil. Similar results have been reported in [13, 17]. In general, the $\mathrm{Cl}$ increased with increasing soil layers for both irrigated and control soils. Similarly, it has been reported that chloride is usually not adsorbed or held back by soils but it moves easily with soil water [16].

Both TWW and FW irrigation had no significant effect on SAR. The results showed an increase of SAR with depth. This significant increase could be explained by the leaching of $\mathrm{Na}^{+}$ into deeper soil. This increase below soil layers disagrees with the findings of [18] which noted that SAR diminished with increasing depth. The high level of SAR $(>13)$ indicated that TWW irrigation increased the soil sodicity.

Result showed that $\mathrm{Cu}$ concentration was significantly higher in the TWW irrigated soil than in the control soil. Our results corroborate with these obtained in [16]. On the other hand, it has also been reported in [2] that the application of wastewater had no significant effect on the amount of $\mathrm{Cu}$ compared with the beginning stage and with the groundwater treatment. In fact, Saber in [26] showed that a seven-year application of wastewater had no significant effect on the concentration of $\mathrm{Cu}$ in the soil. Also, Adriano [27] stated that $\mathrm{Cu}$ is stabilized in soil by clay minerals, organic matters and $\mathrm{Fe}, \mathrm{Al}$ and $\mathrm{Mn}$ oxides. The vertical distribution changed over time with alternation of increase and decrease trend. This tendency agrees with [28] where it is reported that $\mathrm{Cu}$ has certain mobility from upper horizons to lower horizons.

The Co level increased significantly in TWW irrigated soil. These results were in accordance with [2] where it is reported that TWW irrigation had a significant increase on the amount of Co compared with the beginning of the growing season and with the groundwater treatment. In [29] it was reported that application of wastewater for irrigation for a period of 47 years caused a significant increase of the total and available Co in soil. In general, the accumulation of Co increases with increased soil depth and these results were in accordance with those in [2].

As for Zn, application of TWW had no significant effect on the accumulation of $\mathrm{Zn}$. These results are in agreement with findings obtained previously [2]. However, a significant increase of $\mathrm{Zn}$ concentration was shown in 90-120 cm depth. These results contradict the findings in [30] where a significant accumulation of $\mathrm{Zn}$ in the upper $(25-30 \mathrm{~cm})$ soil with wastewater irrigation was reported. This increase might be attributed to the leaching and displacement of $\mathrm{Zn}$ by irrigation into upper soil layers. We can, also, deduce that $\mathrm{Zn}$ concentration in FW irrigated soil decreased compared with the control soil.

Application of TWW increased significantly the $\mathrm{Cd}$ content. Similar results were observed in [31] where it is reported that the concentration of $\mathrm{Cd}$ in soil irrigated under wastewater was increased. On the other hand, in $[10,20,32]$ it was shown that irrigation with wastewater does not effect the concentration of cadmium. Overall, the Cd levels in various soil depths were similar and no tendency was noted. These results were in concordance with those obtained in [33].

Result for $\mathrm{Pb}$ showed that, with the exception of the surface layer, TWW irrigation had no significant effect on the soil. Similar results were reported in $[2,10]$. Moreover, no significant effect was noted regarding depth. However, many authors have shown a significant decrease of $\mathrm{Pb}$ through the soil layers [33, 34]. The $\mathrm{Pb}$ content was reduced in FW irrigated soil. These results might be explained by the lixiviation of the element in soil due to precipitation events after irrigation season $[35,36]$.

In the case of Nickel, soil irrigated with TWW exhibited significant decrease of this metal in comparison with the control soil. These results were in disagreement with [19]. Ni level was higher in all depths of TWW irrigated soils compared to both other cases (control and FW treatment). This is in line with finding reported in [37]. According to our study, no differences were found for soil depth expected the slight 
increase of $\mathrm{Ni}$ in the TWW soil in the depth of $90-120 \mathrm{~cm}$. In similar way, McLaren et al. [28] found that about $57 \%$ of $\mathrm{Ni}$ applications were lixiviated from upper soil horizons to lower soil horizons.

Based on our study, the concentration of heavy metals ( $\mathrm{Zn}$, $\mathrm{Co}, \mathrm{Cu}, \mathrm{Cd}, \mathrm{Pb}$ and $\mathrm{Ni}$ ) was higher in most of depths of TWW irrigated soil compared to those of FW irrigated soil. It has been reported that high concentration of heavy metals in wastewater leads to an increase of their content in soil [31, 3739].

Heavy metals are priority toxic pollutants that severely limit the beneficial use of water [40]. Soil may adsorb and retain important amount of heavy metals from wastewater. In this study, the comparison of $\mathrm{Zn}, \mathrm{Cu}, \mathrm{Pb}$ and $\mathrm{Ni}$ with a standard level of heavy metals in soil showed that $\mathrm{Cd}$ and $\mathrm{Ni}$ of control soil and soils irrigated with the both TWW and FW were higher than their maximum permissible limit (3 and $50 \mathrm{ppm}$ ) in soil by USEPA ([41]). It can be predicted that $\mathrm{Cd}$ and $\mathrm{Ni}$ have been, probably added to the water and soil from other sources. The results for $\mathrm{Zn}, \mathrm{Cu}, \mathrm{Pb}$ were far less than the USEPA maximum permissible limits (50, 200 and $300 \mathrm{ppm})$. The contamination of soil by some heavy metals as $\mathrm{Cd}$ and $\mathrm{Ni}$ presents a worrying situation that should be monitored to prevent further environmental and health risks.

\section{CONCLUSION}

This study contributes to the evaluation of TWW effects on clay-loam soil properties, in order to test the possibility of TWW safe reuse. Indeed, after one cycle of irrigation, we found some variations in the soil properties as a result of TWW application. We have detected an increase in $\mathrm{EC}, \mathrm{Na}, \mathrm{K}, \mathrm{Ca}$, $\mathrm{Mg}, \mathrm{Cl}, \mathrm{SAR}, \mathrm{Cu}, \mathrm{Cd}$ and $\mathrm{Ni}$ content in soil irrigated with TWW in comparison with soil irrigated with FW. However, no remarkable changes in soil $\mathrm{pH}, \mathrm{Zn}, \mathrm{Co}$ and $\mathrm{Pb}$ was shown. We saw a significant increase in $\mathrm{EC}, \mathrm{Na}, \mathrm{Cl}, \mathrm{SAR}, \mathrm{Zn}, \mathrm{Co}$ and $\mathrm{Ni}$ level with depth. But, no significant change in $\mathrm{pH}, \mathrm{K}, \mathrm{Cu}, \mathrm{Cd}$, $\mathrm{Pb}$ and $\mathrm{Ni}$ was shown, for different depths. The results of this study show that TWW reuse in irrigation must be conditioned by some management measures such as soil texture, plant selection and the choice of irrigation methods.

\section{ACKNOWLEDGMENT}

This study was carried out under the INRGREF/ACSADICBA project for the safe reuse of TWW in Arab agriculture and PISEAU II project for TWW and Sludge use in agriculture.

\section{REFERENCES}

[1] A. M. Hassanli, M. Javan, Y. Saadat, "Reuse of municipal effluent with drip irrigation and evaluation the effect on soil properties in a semi-arid area”, Environ. Monit. Assess., Vol. 144, pp. 151-158, 2009

[2] J. Abedi-Koupai, B. Mostafazadeh-Fard, M. Afyuni, M. R. Bagheri, "Effect of treated wastewater on soil chemical and physical properties in an arid region", Plant Soil Environ., Vol. 52, pp. 335-344, 2006

[3] USEPA, Environmental Protection Agency, Offices of water and wastewater and compliance, (Ed.) Guidelines for water reuse, U.S. EPA, Washington, W. A. State Water Strategy, 1992
[4] A. Gregory, "Strategic direction of water recycling in Sydney", the First Symposium Water Recycling, Australia, Adelaide, pp.35-41, 2000

[5] P. Madejon, T. Maranon, J. M. Murillo, "Biomonitoring of trace elements in the leaves and fruits of wild olive and holm oak trees", Sci. Total Environ., Vol. 355, pp. 187-203, 2006

[6] M. Heidarpour, B, Mostafazadeh-Fard, J. AbediKoupai, R. Malekian, "The effects of treated wastewater on soil chemical properties using subsurface and surface irrigation methods", Agric. Water Man., Vol. 90, No. 1-2, pp. 87-94, 2007

[7] K. Aggeli, I. K. Kalavrouziotis, S. Bezergianni, "A proposal of a treated wastewater reuse design system in urban areas", Fresenius Environmental Bulletin, No 18, No. 7b, pp. 1295-1301, 2009

[8] Y. Lui, H.L. Xu, K. Y. Show, J. H. Tay, "Anaerobic granulation technology for wastewater treatment", World Journal of Microbiology \&. Biotechnology., Vol. 18, pp. 99-113, 2002.

[9] B. Jimenez-Cisneros, "Wastewater reuse to increase soil productivity", Water Science and Technology, Vol. 32, No. 12, pp. 173-180, 1995

[10] M. J. Rusan, S. Hinnawi, L. Rousan, "Long term effect of wastewater irrigation of forage crops on soil and plant quality parameters", Desalination, Vol. 215, No. 1-3, pp. 143-152, 2007

[11] R. K. Rattan, S. P. Datta, P. K. Chhonkar, K. Suribabuand, A. K. Singh, "Long-term impact of irrigation with sewage effluents on heavy metal content in soils, crops and groundwater- A case study", Agric. Ecosyst. Environ., Vol. 109, No. 3-4, pp. 310-322, 2005

[12] M. Jahantigh, "Impact of Recycled Wastewater Irrigation on Soil Chemical Properties in an Arid Region", Pak J Biol Sci, Vol.11, No. 18, pp. 2264-2268, 2008

[13] A. Mojiri, "Effects of Municipal Wastewater on Physical and Chemical Properties of Saline Soil", J. Biol. Environ. Sci., Vol. 5, No. 14, pp 7176, 2011

[14] G. A. Al-Nakshabandi, M. M. Saqqar, M. R. Shatanawi, M. Fayyadand, H. Al- Horani, "Some environmental problems associated with the use of treated wastewater for irrigation in Jordan", Agricultural Water Management, Vol. 34, No. 1, pp. 81-94, 1997

[15] F. M. Kiziloglu, M. Turan, U. Sahina, Y. Kuslu, A. Dursun, "Effects of untreated and treated wastewater irrigation on some chemical properties of cauliflower (Brassica olerecea L. var. botrytis) and red cabbage (Brassica olerecea L. var. rubra) grown on calcareous soil in Turkey", Agricultural Water Management, Vol. 95, No. 6, pp. 716-724, 2008

[16] G. L. Tarchouna, P. Merdy, M. Raynaud, H. R. Pfeifer, Y. Lucas, "Effects of long-term irrigation with treated wastewater, Part I: Evolution of soil physico-chemical properties", Applied Geochemistry, Vol. 25, No. 11, pp. 1703-1710, 2010

[17] P. Najafi, S. Nasr, "Comparison effects of wastewater on soil chemical properties in three irrigation methods", Research on Crops, Vol. 10, No. 2, pp. 277-280, 2009

[18] G. Murtaza, A. Ghafoor, M. Qadir, M.K. Rashid, "Accumulation and bioavailability of $\mathrm{Cd}, \mathrm{Co}$ and $\mathrm{Mn}$ in soils and vegetables irrigated with City Effluent”, Pak. J. Agri. Sci., Vol. 40, No. 1-2, pp. 18-24, 2003

[19] S. Vaseghi, M. Afyuni, H. Shariatmadari, M. Mobli, "Effect of sewage sludge on some nutrients concentration and soil chemical properties", Journal of Isfahan Water and Wastewater, Vol. 53, pp. 15-19, 2005

[20] M. J. Mohammad, N. Mazahreh, "Changes in soil fertility parameters in response to irrigation of forage crops with secondary treated wastewater", Communications in Soil Science and Plant Analysis, Vol. 34, No. 9-10, pp. 1281-1294, 2003

[21] R. P. Gambrell, "Trace and toxic metals in wetlands-a review", Journal of Environmental Quality, Vol. 23, No. 5, pp. 883-891, 1994

[22] D. W. Sparling, T. P. Lowe, "Metal concentrations in aquatic macrophytes as influenced by soil and acidification", Water, Air and Soil Pollution., Vol. 108, No. 1-2, pp. 203-221, 1998

[23] R. N. Cromer, D. Tompkins, N. J. Barr, P. Hopkins, "Irrigation of monterey pine with wastewater: Effect on soil chemistry and groundwater composition", Journal of Environmental Quality, Vol. 13 No. 4, pp. 539-542, 1984 
[24] H. Stewart, P. Hopmans, D. Flinn, T. Hillman, "Nutrient accumulation in trees and soil following irrigation with municipal effluent in Australia”, Environ. Pollut., Vol. 63, pp. 155-177, 1990

[25] C. F. Manchino, I. L. Pepper, "Irrigation of turfgrass with secondary sewage effluent: soil quality", Agron. J., Vol. 8, pp. 650-654, 1992

[26] M. S. M. Saber, "Prolong effect of land disposal of human waste on soil conditions", Water Science \& Technology, Vol. 18, No. 7-8, pp. 371374,1996

[27] D. C. Adriano, Trace elements in terrestrial environments, SpringerVerlag, New York, 2001

[28] R. G. McLaren, L. M. Clucas, M. D. Taylor, "Leaching of macronutrients and metals from undisturbed soils treated with metalspiked sewage sludge”, Soil Research, Vol. 43, pp. 159-170, 2005

[29] M. B. Pescod, A. Arar (eds), "Treatment and use of sewage effluent for irrigation", Proceedings of the FAO Regional Seminar on the Treatment and Use of Sewage Effluent for Irrigation Held in Nicosia, Cyprus, 7-9 October, 1985

[30] S. Lawes, "Analysis of heavy metal-contaminated soil and anaerobically digested sewage sludge", B.Sc. Thesis, Department of Agric. Chem. and Soil Sci., University of Sydney, 1993.

[31] M. S. Brar, M. P. S. Khurana, B. D. Kansal, "Effect of irrigation by untreated sewage effluents on the micro and potentially toxic elements in soils and plants", $17^{\text {th }}$ World Congress Soil Sci., Bangkok, Thailand, pp. 198-1-198-10, 2002

[32] A. Mojiri, A. Jalalian, H. Radnezhad, "Effects of urban wastewater treatments on chemical properties of saline and alkaline soil", Journal of Applied Sciences Research, Vol. 7, pp. 222-228, 2011

[33] V. M. Maldonado , H.O. Arias, R. Quintana, R. A. Saucedo, M. Gutierrez, J. Ortega, G. Nevarez, "Heavy metal content in soils under different wastewater irrigation patterns in Chihuahua, Mexico", Int. J. Environ. Res. Public Health, Vol. 5 pp. 441-449, 2008

[34] B. A. Adelekan, A. O. Alawode, "Contributions of refuse dumps to heavy metal concentrations in soil”, J. Appl. Biosci., Vol. 40, pp $2727-$ 2737, 2011

[35] D. P. Stevens, M. J. McLaughlin, T. Heinrich, "Determining toxicity of lead and zinc runoff in soils: Salinity effects on metal partitioning and on phytotoxicity”, Environ. Toxicol. Chem., Vol. 22, pp. 2017-3024, 2003

[36] M. Bongers, B. Rusch, C. A. Van Gestel, "The effect of counterion and percolation on the toxicity of lead for the springtail Folsomia candida in soil", Environ. Toxicol. Chem., Vol. 23, No. 1, pp 195-199, 2004

[37] F. Mapanda, E. N. Mangwayana, J. Nyamangara, K. E. Giller, "The effect of longterm irrigation using waste water on heavy metal contents of soils under vegetables in Harare Zimbabwe", Agriculture, Ecosystems \& Environment, Vol. 107, No. 2-3, pp. 151-165, 2005

[38] L. Huerta, R. Contreras-Valadez, S. Palacios-Mayorga, J. Miranda, G. Calva-Vasquea, "Total elemental composition of soils contaminated with waste water irrigation by combining IBA techniques", Nuclear Instruments and Methods in Physics Research Section B, Vol. 189, pp. 158-162, 2002

[39] Z. Nan, J. Li, J. Zhan, G. Cheng, "Cadmium and zinc interaction and their transfer in soil-Crop system under actual field conditions", Sci. Total Environ., Vol. 1, pp. 187-195, 2002

[40] R. Petrus, J.K. Warchol, "Heavy metal removal by clinoptilolite: an equilibrium study in multi-component systems", Water Research, Vol. 39, No. 5, pp. 819-830, 2005

[41] C. Masona, L. Mapfaire, S. Mapurazi, R. Makanda, "Assessment of heavy metal accumulation in wastewater irrigated soil and uptake by maize plants (zea mays 1) at firle farm in Harare", Journal of Sustainable Development, Vol. 4, No. 6, pp. 132-137, 2011 